\title{
Discussion on Balanced Development of Network Education Resources of College Physical Education
}

\author{
Ma Zhenlei \\ Wushu Department \\ Hebei Sport University \\ Shijiazhuang, China \\ 516210920@qq.com
}

\author{
Jiang Huabei \\ Wushu Department \\ Hebei Sport University \\ Shijiazhuang, China \\ 714332974@qq.com
}

\author{
Xu Hailong \\ Wushu Department \\ Hebei Sport University \\ Shijiazhuang, China \\ xuhailonghebei@yahoo.com.cn
}

\begin{abstract}
In this paper, internet survey has been taken to carry out a comparative study of regional distribution and development changes of network education resources of national college physical education. The result shows that the construction of network resources of national college physical education presents an increasing tendency, and the quality of construction has been improved greatly. But, at the same time the construction of physical education network education resources in different regions presents imbalanced development. Development countermeasure has been proposed against this current situation in this paper to decision-making department for reference.
\end{abstract}

Keywords- Physical education network, Network education, Education resources, Balanced development.

\section{INTRODUCTION}

Network education resources are usually formed by the addition, upgrade or regeneration of traditional education resources, the construction of network resources is process of resources regeneration. Education resources contain education theory, education administration, education resources etc. in general, for instance, electronic teaching plan, electronic courseware and electronic library. In the aspect of college physical education, physical education network information technology should be used extensively to promote prosperous development of network education college physical education. However the development of network education resources of national college physical education is still insufficient comparing with the development of modern network information technology. Thus it has been an important task of network education information of college physical education to strength analysis of network education resources construction of college physical education, and to lead construction and development of network education resources correctly.

During “The Eleventh Five-Year Plan”, the construction and application of network education resources of college physical education has developed rapidly, but the development is highly imbalanced with large difference of construction level. In this paper, construction and development situation and distribution of different regions of network education resources of national college physical education has been analyzed, comparative analysis of network education resources construction statistical data of college physical education in different regions has been taken, and objective evaluation of development level of different regions has been made by investigation and research of network education resources construction of college physical education directly subordinate to Ministry of Education in 2004 and 2009 (the group in 2004 called group 04, the group in 2009 called group 09). At the same time, this paper predicts development tendency of network education resources of college physical education in the future, and puts forward constructive suggestions for network education resources construction and development of national colleges and universities physical education.

This paper intends to grade construction quality and application level of physical education network education resources. Considering that there is no widely accepted uniform evaluation standard, referring to network courseware evaluation standard of management information center of the Ministry of Education and network resources evaluation standard of national essential courses, proposing generalized evaluation standard framework for three-grade evaluation. Marking basis of calculation as follows: 20 scores for teaching content evaluation, including scientificity and normativity of resources, knowledge hierarchy, and resources application; 20 scores for instructional design evaluation, including object organization and academic environment; 20 scores for technical evaluation, including operating ambient, design level and media applications; 20 scores for artistic quality evaluation, including interfacial effect and media effect; 20 scores for resources characteristic evaluation, including teaching feedback, popularization and application, innovation and originality. 100 points totally. The threegrade evaluation criterion contains average level resources (below 75 points), middle level resources (75 89 points), and high level resources (above 90 points).

The writer divided sample survey scores and expert evaluation results in groups by regions, counted survey results of 2009 and that of 2004 in group, and carried out analysis and comparison of network education resources construction of national college physical education in different regions by using statistical method of matched pairs design. This paper has carried out a significance test aim at differences of network education resources construction level of college physical education of group 09 and group 04; and carried out a test of ensemble average differences between group 09 and group 04 by using matched pairs design. 


\section{DEMONSTRATION SURVEY RESUlts ANALYSIS}

Table 1 shows distribution of network education resources construction of national college physical education counted according to sample collection scheme.

First, table 1 show that which the statistics data of group 04 indicates that there are 334 universities equipped with network education resources of college physical education during “The Tenth Five-Year Plan”. Among, there are 59 colleges with high level network resources, 136 colleges with middle level network resources, 139 colleges with average level network resources, and accounting for $17.66 \%, 40.7 \%$ and $41.62 \%$ of college physical education network education resources respectively. The other survey statistics data of group 09 indicates that there are 847 universities with network education resources of college physical education during “The Eleventh Five-Year Plan”. Among, there are 338 colleges with high level network resources, 316 colleges with middle level network resources, 316 colleges with average level network resources, and accounting for $39.91 \%, 37.71 \%$ and $22.08 \%$ of college physical education network education resources respectively. The proportion of college with high level network resources has increased by $22.25 \%$. (Shown in table 2)

Analyzing from universities type of national college physical education network education resources construction, the proportion of high level resources construction universities presents imbalanced situations: high level resources construction of comprehensive universities account for 56.3\%, high level resources construction of engineering colleges account for $60.32 \%$, high level resources construction of normal physical education colleges account for $68.87 \%$, and high level resources construction of economic universities account for 45.31\%; High level resources construction of "211 Project" construction universities account for $65.4 \%$. Thus it can be seen that the construction level of high level physical education network education resources of comprehensive universities is higher than that of general universities.

Second, the matched test results of network education resources construction level changes of national college physical education indicate that proportion of universities which completed physical education network education resources construction has been improved greatly. Analyzing from network education resources construction and application level of college physical education, proportion of universities which with average level network resources and that of universities which with middle level network resources changes indistinctively in recent years, and proportion of universities which with high level network resources construction has been improved greatly. It means fully attention has been given to network education resources construction of national college physical education from state and local education departments. Many universities have high starting point at construction of physical education network education resources, pay attention to improving network resources quality, emphasize network resources application in teaching practice, and uses various network interactive learning in teaching.
Third, table 3 shows the possession quantity and construction situation of national college physical education network resources in eastern regions and central and western regions. The economic development of different regions in our country is imbalanced, and economic development gap is increasing between eastern regions and central and western regions. In order to analyze specifically the influence of regional economic development level on college physical education network resources construction, a significance test has been carried out for the difference of proportion of college physical education network education resources level which refers to general level, middle level and high level between eastern regions and central and western regions of our country. The result of test indicates that there are no significant differences of proportion of general level, middle level of resources construction in the region of eastern and central and western, but proportion of high level physical education network education resources of central and western regions is lower than that of eastern regions.

Forth, comparing college physical education network education resources construction among eastern, central and western regions, the physical education network education resources development level of eastern regions is higher than that of central and western regions during "The Eleventh Five-Year Plan”. There are many universities with high level physical education network education resources in eastern regions, the proportion of completed universities with physical education network education resources in eastern regions accounts for $76 \%$ of total universities in survey, it is 15 percentages higher than average value, 25 percentage higher than central regions and 21 percentage higher than western regions (Shown in table 3).

The macro analysis of network education resources construction and development speed of college physical education shows that the network education resources construction presents a higher development speed in eastern and central regions. This has increased respectively by 26 percentages and 13 percentages in eastern and central regions comparing with that of year 2004. And that of western region has increased by 7 percentages with a lower development speed. It is worth noting that universities with high level physical education network education resources configuration have a rapid development speed, compared year 2009 with year 2004, the development speed in eastern, central and western regions has respectively raised 2.3 times, 7 times and 2.4 times, and the development speed in central and western regions is faster than that of eastern regions. It shows universities in central and western regions have paid much more attention to construction of physical education network education resources, and have adopted high standard and high level development scheme on construction of physical education network education resources. Of course, on the overall level, restricted by economic condition and talent, there are obvious differences between central and western regions and eastern regions.

Fifth, construction of college physical education essential courses network resources exerts its exemplary effectiveness of key university. Essential courses 
construction project has been started generally in colleges during "The Fifth Five-Year Plan", to promote research study, and the physical education network education resources start to show its important effects as a part of courses construction. The construction of physical education network education resources has been paid much attention and invested tremendous human and resources in regions, which makes physical education network education resources construction into leap-forward development. From "The Tenth Five-Year Plan" to "The Eleventh Five-Year Plan", the amount of universities with high configuration of network education resources has increased by 15 percentages which shown in table 3 .

Table 4 shows that the implement of physical education network education resources construction of "211 Project" construction universities has obtained great financial support, and a group of high level modernization physical education network education resource library has been completed one after another in colleges. From "The Tenth Five-Year Plan" to "The Eleventh Five-Year Plan", the proportion of physical education network education resources of key universities reached to high level accounts for $65.4 \%$. It explains that the physical education network education resources construction of "211 Project" construction universities reaches a high level.

\section{CONCLUSIONS AND SUGGESTIONS}

All above analysis can be concluded as follows:

First, development data of college physical education network education resources in the recent decade of our country indicate that during "The Eleventh Five-year Plan" the construction of college physical education network education resources has been completed basically, realizing resource sharing among colleges. College physical education network education resources become important and irreplaceable basic education resources in physical education. The construction level of college physical education resources in different regions of the country presents a remarkable and increasing trend.

Third, by comparison of nationwide construction quality of college physical education network education resources, it is founded distribution of these resources presents imbalance situation which continues to exist during "The Eleventh Five-year Plan”. The construction level of college physical education network education resources in the eastern regions is higher than that in the central regions, western regions of the country.

Fourth, by comparison of nationwide developing speed of construction of college physical education network education resources, it is known that the construction of resources in the western or central regions develops quickly, and as a reason of lacking college physical education network education resources, the western regions with undeveloped economy develops more slowly than the western regions in relevant respect.

Fifth, as to development trend of college physical education network education resources, modernized networking and information technology has been adopted in more colleges or universities, which fully embodies characteristics of physical education discipline in various colleges or universities and promotes more wide application of physical education network education resources in physical education. Physical education network education resources between colleges develop in a direction of mutual complementation and resource sharing.

Suggestions as follows:

First, the key of improving quality of network resources is to form obvious characteristics of network education resources of physical education. Three-dimensional network resources of all colleges' physical education majors are scarce with less original resources in them. The research and development mode, which is mainly based on physical education teachers' strength, shall be modified, which will be achieved by cooperation between theory experts of physical education, computer workers and physical education teachers.

Second, promote the application in practice of network education resources of college physical education vigorously, which will need to implement a systematic reform to conventional teaching mode of physical education and conduct bold reforms and innovations on teaching management, teacher evaluation, teacher training, etc.

Third, the construction of network education resources of national college physical education is a great system engineering, which makes colleges that have network education resources superiority in developed regions play significant roles, forms a steady and reliable network application platform, lays solid foundation for informationbased development of national college physical education network and plays a model role.

Fourth, the government shall provide more support to the construction of network education resources of college physical education in the central and western regions and change imbalanced conditions of network education development of national college physical education. The government shall increase funds investment and accelerate development and construction of network education resources of college physical education in the western regions.

\section{REFERENCES}

[1] Chen Zhenxiang, Pan Delun, Lu Hongning. A Research on the Application of Internet Survey in Sport [J]. Journal of Beijing Sport University, 2010, (3).

[2] Yang Ming. The Survey and Analysis of Development of College Physical Education Websites in China [J]. Journal of Tianjin University of Sport, 2004, (5).

[3] Dong Lu. Methods of Data Analysis [M]. Dalian: Dongbei University of Finance \& Economics Press, 2001. 34 55 


\begin{tabular}{|c|c|c|c|c|c|c|c|c|c|}
\hline \multicolumn{2}{|c|}{$\begin{array}{l}\text { Table 1, the rating table of network education resources construction and application of national college physical } \\
\text { education. }\end{array}$} \\
\hline
\end{tabular}

Table 2. the increased percentage of network education resources construction of national college physical education (unit: \%)

\begin{tabular}{|c|c|c|c|c|}
\hline & $\begin{array}{c}\text { Percentage of physical education } \\
\text { network education resources }\end{array}$ & High level & Middle level & Average level \\
\hline Year 2004(\%) & 47.85 & 17.66 & 40.71 & 41.61 \\
\hline Year 2009(\%) & 61.55 & 39.91 & 37.31 & 22.08 \\
\hline Growth rate (\%) & 13.70 & 22.25 & -3.40 & -19.53 \\
\hline \multicolumn{2}{|c|}{ Note: Percentage refers to the proportion accounted all the units in survey. } \\
\hline
\end{tabular}

\begin{tabular}{|c|c|c|c|c|c|c|c|c|}
\hline \multirow[t]{2}{*}{ Regions } & \multicolumn{2}{|c|}{$\begin{array}{ll}\text { Percentage of } & \text { college } \\
\text { physical education } & \text { network } \\
\text { education resources } & \end{array}$} & \multicolumn{2}{|c|}{ High level } & \multicolumn{2}{|c|}{ Middle level } & \multicolumn{2}{|c|}{ Average level } \\
\hline & 2009 & 2004 & 2009 & 2004 & 2009 & 2004 & 2009 & 2004 \\
\hline Eastern & 76 & 50 & 30 & 13 & 28 & 21 & 16 & 17 \\
\hline Central & 51 & 38 & 21 & 3 & 17 & 21 & 14 & 15 \\
\hline Western & 55 & 48 & 17 & 7 & 23 & 18 & 15 & 23 \\
\hline Average & 60.66 & 45.33 & 22.66 & 7.66 & 22.66 & 20 & 15 & 18.33 \\
\hline
\end{tabular}

Table 4, physical education network education resources construction quality table of “211 Project” universities

\begin{tabular}{|c|c|c|c|c|c|c|c|c|}
\hline $\begin{array}{c}\text { Network resources } \\
\text { level }\end{array}$ & \multicolumn{2}{|c|}{ High level } & \multicolumn{2}{c|}{ Middle level } & \multicolumn{2}{c|}{ Average level } & \multicolumn{3}{c|}{ Total } \\
\hline Time & 2006 & 2003 & 2006 & 2003 & 2006 & 2003 & 2006 & 2003 \\
\hline Amount & 68 & 33 & 26 & 30 & 10 & 12 & 104 & 75 \\
\hline Percentage & 65.40 & 34 & 25 & 31.40 & 9.60 & 12.60 & 96.30 & 78.95 \\
\hline
\end{tabular}

Note: Total amount of universities is 107 of Year 2006 which there are 12 universities added. The valid data is 104 without statistics data of three universities, because of network or the other factors. 